\title{
Survey of Toxoplasma gondii and Neospora caninum, haemotropic mycoplasmas and other arthropod-borne pathogens in cats from Albania
}

\author{
Cornelia Silaghi ${ }^{1 *}$, Martin Knaus $^{2}$, Dhimiter Rapti ${ }^{3}$, Ilir Kusi ${ }^{3}$, Enstela Shukullari ${ }^{3}$, Dietmar Hamel ${ }^{2}$, Kurt Pfister ${ }^{1}$ \\ and Steffen Rehbein ${ }^{2}$
}

\begin{abstract}
Background: Albania is a country on the western part of the Balkan Peninsula. The Mediterranean climate is favourable for the stable development of many arthropod species, which are incriminated as vectors for various agents. Recently, several papers have reported on epidemiological aspects of parasitic diseases including vector-borne disease agents of dogs with zoonotic characteristics in Albania. However, data on the epidemiology of feline parasitic and bacterial agents in Albania is scarce.
\end{abstract}

Methods: Serum and EDTA-blood samples collected from 146 domestic cats from Tirana during 2008 through 2010 were examined for exposure to Toxoplasma gondii, Neospora caninum, Leishmania infantum, and Anaplasma spp. with IFAT, for infection with L. infantum, A. phagocytophilum, Bartonella spp. and haemotropic mycoplasmas with conventional PCR and real-time PCR and for Dirofilaria immitis with antigen ELISA. Additionally blood smear microscopy was carried out for detection of blood-borne pathogens.

Results: Antibodies to T. gondii (titre $\geq 1: 100$ ) were demonstrated in 91 cats (62.3\%). Antibodies to N. caninum (titre $\geq 1: 100$ ), L. infantum (titre $\geq 1: 64$ ) and Anaplasma spp. (titre $\geq 1: 100$ ) were found in the serum of $15(10.3 \%), 1(0.7 \%)$ or $3(2.1 \%)$ cats, respectively. DNA of haemotropic mycoplasmas was detected in the blood of 45 cats (30.8\%), namely Candidatus Mycoplasma haemominutum (21.9\%), Mycoplasma haemofelis (10.3\%), and Candidatus Mycoplasma turicensis (5.5\%), with ten cats harbouring co-infections of two mycoplasmas each; blood from one cat was PCR positive for Bartonella henselae. No DNA of Leishmania spp. and A. phagocytophilum or circulating D. immitis antigen was detected in any cat sample. The overall prevalence of haemotropic mycoplasmas was significantly higher in male compared to female cats ( $40.6 \%$ vs. $24.1 \%, p=0.0444)$; and age was associated positively with the prevalence of antibodies to T. gondii $(p=0.0008)$ and the percentage of haemotropic mycoplasma infection $(p=0.0454)$.

Conclusions: With the broad screening panel including direct and indirect methods applied in the present study, a wide spectrum of exposure to or infection with parasitic or bacterial agents was detected.

Keywords: Cat, Albania, Toxoplasma gondii, Neospora caninum, Leishmania infantum, Anaplasma spp., Bartonella henselae, haemotropic mycoplasmas

\footnotetext{
* Correspondence: cornelia.silaghi@tropa.vetmed.uni-muenchen.de

'Chair of Comparative Tropical Medicine and Parasitology, Faculty of Veterinary Medicine, Ludwig-Maximilians-Universität München, Leopoldstraße 5, 80802 Munich, Germany

Full list of author information is available at the end of the article
} 


\section{Background}

Albania is a country on the western part of the Balkan Peninsula that extends to the south from central Europe into the Mediterranean Sea. The country is bordered by Montenegro to the northwest, Kosovo to the northeast, Former Yugoslav Republic of Macedonia to the east and Greece to the south and southeast. Albania has a coast on the Adriatic Sea to the west and on the Ionian Sea to the southwest, and is less than $75 \mathrm{~km}$ from southern Italy, across the Strait of Otranto. The climate is Mediterranean on the Adriatic coast, but the mountainous interior of Albania has a humid continental climate with frosty and snowy winters, especially in the north-eastern part of the country.

The Mediterranean Basin is considered as a region where zoonoses are widespread and most numerous as regards variety, but often receives insufficient attention to specifically assess its situation. Dogs especially, but cats too, may act as reservoirs of pathogens of zoonotic concern as populations of dogs and cats are numerous in both urban and rural areas. Among other factors, the mild Mediterranean climate is favourable for the stable development of many arthropod species, which are incriminated as vectors for various agents $[1,2]$.

Due to its history, Albania can be considered as a relatively uncharted country with respect to canine and feline diseases, including infections of zoonotic importance. Recently, several papers reported on aspects of the epidemiology of parasites including vector-borne disease agents of dogs with zoonotic character in Albania [3-7]. The knowledge regarding cats, however, is limited to preliminary data on parasites of internal organs, arthropod ectoparasites and the detection of zoonotic bacterial pathogens in fleas collected from cats [8-10].

The objective of this study was to assess exposure to or infection with Toxoplasma gondii and Neospora caninum, as well as bacterial and parasitic arthropod-transmitted pathogens, in serum and blood samples of cats from the capital Tirana by serological and molecular detection methods.

\section{Methods}

\section{Animals}

EDTA-blood and serum samples were collected from 146 (59 male, 87 female) clinically normal, free-roaming cats from suburban areas from Tirana, Albania, on four occasions either in summer (June/July, 75 cats) or autumn (October/November, 71 cats) during 2008 to 2010. The age of the cats ranged from approximately three months up to five years. The cats were categorized into the following age groups: kittens, $<6$ months $(n=33)$; juveniles, $>6$ and up to 12 months $(\mathrm{n}=39)$; young adults, $>12$ and up to 36 months $(\mathrm{n}=43)$; adults, $>36$ months $(\mathrm{n}=31)$. Blood samples were frozen after collection with the exception of a total of 82 samples. Examination of the cats for ectoparasites revealed infestation with 1 to 50 fleas on 71 cats (total 320 Ctenocephalides felis and 5 Ctenocephalides Ctenocephalides canis), and a single female Rhipicephalus sanguineus tick was found on one other cat. As reported previously, the fleas collected from those cats and another seven cats were analyzed for the presence of flea-borne zoonotic pathogens, i.e. Bartonella spp. and Rickettsia spp. [10].

\section{Serology}

Sera were tested for the presence and the level of IgG antibodies against T. gondii, N. caninum, Anaplasma phagocytophilum and Leishmania infantum by indirect fluorescent antibody test (IFAT). A commercial test available for cat serum was used for $T$. gondii with controls and conjugate provided in the kit (MEGASCREEN ${ }^{\ominus}$ FLUO TOXOPLASMA gondii Test Kit antifeline). N. caninum and $A$. phagocytophilum were also tested with commercial kits, [MEGASCREEN $^{\circledR}$ FLUO NEOSPORA c., MEGASCREEN ${ }^{\circ}$ FLUO ANAPLASMA ph. (MegaCor, Hörbranz, Austria)] with FITC labeled anti-cat IgG conjugate (Sigma-Aldrich, Taufkirchen, Germany). For anti-L. infantum antibody detection, an in-house IFAT was used with L. infantum promastigote stages derived from cell culture serving as antigen [11].

In the absence of validated IFAT for felines, visible cytoplasmatic/membrane fluorescence ( $N$. caninum, L. infantum) or fluorescence of cytoplasmatic morulae (A. phagocytophilum) was considered as seroreactive.

Two-fold serial dilutions were made starting from 1:25 (T. gondii, N. caninum, A. phagocytophilum) or $1: 32$ (L. infantum). Reactions at a dilution of $\geq 1: 64$ for $L$. infantum or $\geq 1: 100$ for $T$. gondii, N. caninum, and A. phagocytophilum were considered positive; positive serum was serially diluted to 1:800 ( $N$. caninum, A. phagocytophilum), 1:1600 (T. gondii), or 1:512 (L. infantum). Positive control sera for $T$. gondii were provided by the manufacturer of the test kit and by Dr. Sándor Hornok (Institute for Parasitology and Zoology, Faculty of Veterinary Medicine, Szent Istvan University, Budapest, Hungary) who also provided a $N$. caninum-positive cat serum sample. For Leishmania and Anaplasma, feline serum samples obtained from the routine diagnostic centre of the Institute of Comparative Tropical Medicine and Parasitology in Munich, with titres of $>1: 256$, were used as positive controls.

The DiroCHEK ${ }^{\oplus}$ Canine/Feline Antigen Test Kit (Synbiotics Corp., San Diego, USA) was employed for the detection of circulating female adult heartworm proteins (Dirofilaria immitis).

\section{Direct pathogen detection and molecular biological analysis}

A Giemsa-stained blood smear from each cat was microscopically examined for intra- and extracellular pathogens, 
and the Knott's test was used to detect microfilariae in a subset of 82 blood samples, which had not been frozen after sampling.

DNA was extracted from the EDTA-blood with a commercial kit according to the manufacturer's instructions for blood (QIAamp DNA MiniKit, Qiagen, Hilden, Germany). Quality and quantity of the extracted DNA were checked with a spectrophotometer (NanoDrop ${ }^{\circ} 1000$, Peqlab, Erlangen, Germany).

Conventional PCRs were carried out for detecting DNA of Bartonella spp. [12], Mycoplasma haemofelis and Candidatus Mycoplasma haemominutum [13]. Species identification can be carried out according to species-specific length of the PCR-products. Primers and PCR conditions used are listed in Table 1. The HotMaster Taq DNA Polymerase Kit (5PRIME, Darmstadt, Germany) was used. For the specific detection of DNA of L. infantum [14], A. phagocytophilum [15] and Candidatus Mycoplasma turicensis [16] real-time PCR were carried out in an AB7500 (Applied Biosystems, Darmstadt, Germany) using the TAQMAN ${ }^{\circ}$ GENEEXPRESSION MasterMix (Applied Biosystems, Darmstadt, Germany), according to the instructions of the manufacturer and with primers and probes under conditions summarized in Table 1. Positive and negative controls were included in each PCR run. The products of conventional PCRs were examined under UV-light, after 2\% agarose gel electrophoresis and staining with GelRed ${ }^{\mathrm{mm}}$ (Biotium, Hayward, USA).

\section{Statistical analysis}

Exact 95\% confidence intervals (95\% CI) for the percentages of seropositivity or prevalences of pathogens were calculated with the Clopper and Pearson method. Fisher's exact test or chi-squared statistics were used to test for associations of the analytical results with gender and age of the cats, season of sample collection or between analytical results themselves. P-values $<0.05$ were considered as significant.

This study was approved by the ethical committee of the Universiteti Bujqësor, Fakulteti i Mjeksise Veterinare, Tirana, Albania.

\section{Results}

A total of $63.7 \%$ of the 146 cats tested positive in the indirect detection tests, as well as $31.5 \%$ with direct test methods, resulting in $72.6 \%$ of the 146 cats with evidence for exposure to T. gondii, N. caninum, L. infantum and/or Anaplasma spp., and/or infection with Bartonella henselae or haemotropic mycoplasmas.

\section{Serological examination}

Ninety-one out of 146 feline serum samples (62.3\%, 95\% CI 53.9 - 70.2) were found positive (IFAT titre $\geq 1: 100$ ) for T. gondii (Table 2). For 14 other cats, borderline titres of 1:50 were obtained. Further titration of the 91 IFAT positive serum samples showed that 76 of the 91 (85.7\%, 95\% CI 76.8 - 92.2) seropositive cats had highly reactive titers of $1: 800$ or higher.

Table 1 Summary of specific PCR and real-time PCR methods used in this study on cats from Albania

\begin{tabular}{|c|c|c|c|}
\hline Target & Primers 5'-3' & Cycle conditions & Reference \\
\hline \multicolumn{4}{|c|}{ Conventional PCR methods } \\
\hline \multirow{2}{*}{$\begin{array}{l}\text { Bartonella spp. 16S-23S ITS } \\
\text { (154-260 bp) B. henselae: } 172 \text { bp }\end{array}$} & Barhen1_for: YCTTCGTTCTCTTCTTCA & \multirow{2}{*}{$\begin{array}{l}44 \text { cycles: } 30 \mathrm{Sec} 94^{\circ} \mathrm{C}, 30 \mathrm{Sec} 60^{\circ} \mathrm{C} \text {, } \\
30 \mathrm{Sec} 72^{\circ} \mathrm{C}\end{array}$} & \multirow[t]{2}{*}{ [12] } \\
\hline & Barhen2_rev: AACCAACTGAGCTACAAGCC & & \\
\hline \multirow{3}{*}{$\begin{array}{l}\text { Mycoplasma haemofelis/Candidatus } \\
\text { M. haemominutum } 165 \text { rRNA gene } \\
\text { (274 bp/202 bp respectively) }\end{array}$} & OHOK1_for: ATGCCCCTCTGTGGGGGATAGCCG & \multirow[t]{3}{*}{$\begin{array}{l}35 \text { cycles: } 45 \operatorname{Sec} 94^{\circ} \mathrm{C}, 45 \mathrm{Sec} 58^{\circ} \mathrm{C} \text {, } \\
45 \mathrm{Sec} 72^{\circ} \mathrm{C}\end{array}$} & \multirow[t]{3}{*}{ [13] } \\
\hline & CaB2_for: CTGGGAAACTAGAGCTTCGCGAGC & & \\
\hline & OOCBr1_rev: ATGGTATTGCTCCATCAGACTTTCG & & \\
\hline \multicolumn{4}{|l|}{ Real-time PCR methods } \\
\hline \multirow{3}{*}{$\begin{array}{l}\text { Leishmania infantum } \\
\text { Kinetoplast } 700 \mathrm{bp}\end{array}$} & Lsh-kF: CTTTCTGGTCCTCCGGGTAGG & \multirow{3}{*}{$\begin{array}{l}\text { All Real-time PCR methods: } 2 \text { min } 50^{\circ} \mathrm{C} \text {, } \\
10 \text { min } 95^{\circ} \mathrm{C}, 40 \text { cycles: } 15 \mathrm{Sec} 95^{\circ} \mathrm{C}, \\
1 \text { min } 60^{\circ} \mathrm{C}\end{array}$} & \multirow[t]{3}{*}{ [14] } \\
\hline & Lsh-kR: CCACCCGGCCCTATTTTACACCAA & & \\
\hline & Lsh-kp: FAM-TTTCGCAGAACGCCCCTACCCGC-BHQ1 & & \\
\hline \multirow{3}{*}{$\begin{array}{l}\text { Anaplasma phagocytophilum: } \\
\text { Msp2 gene (77 bp) }\end{array}$} & ApMSP2f: ATGGAAGGTAGTGTTGGTTATGGTATT & & \multirow[t]{3}{*}{ [15] } \\
\hline & ApMSP2r: TTGGTCTTGAAGCGCTCGTA & & \\
\hline & ApMSP2p-FAM: TGGTGCCAGGGTTGAGCTTGAGATTG & & \\
\hline \multirow{3}{*}{$\begin{array}{l}\text { Candidatus M. turicensis } 16 \mathrm{~S} \\
\text { rRNA gene (85 bp) }\end{array}$} & HS Real2_for: GAAGGCCAGACAGGTCGTAAAG & & \multirow[t]{3}{*}[16]{} \\
\hline & HS Real2_rev: CTGGCACATAGTTWGCTGTCACTTA & & \\
\hline & HS RealT: FAM-AAATTTGATGGTACCCTCTGA-MGB & & \\
\hline
\end{tabular}


Table 2 Details of cats that tested seropositive (IFAT titre $\geq 1: 100$ ) for Toxoplasma gondii

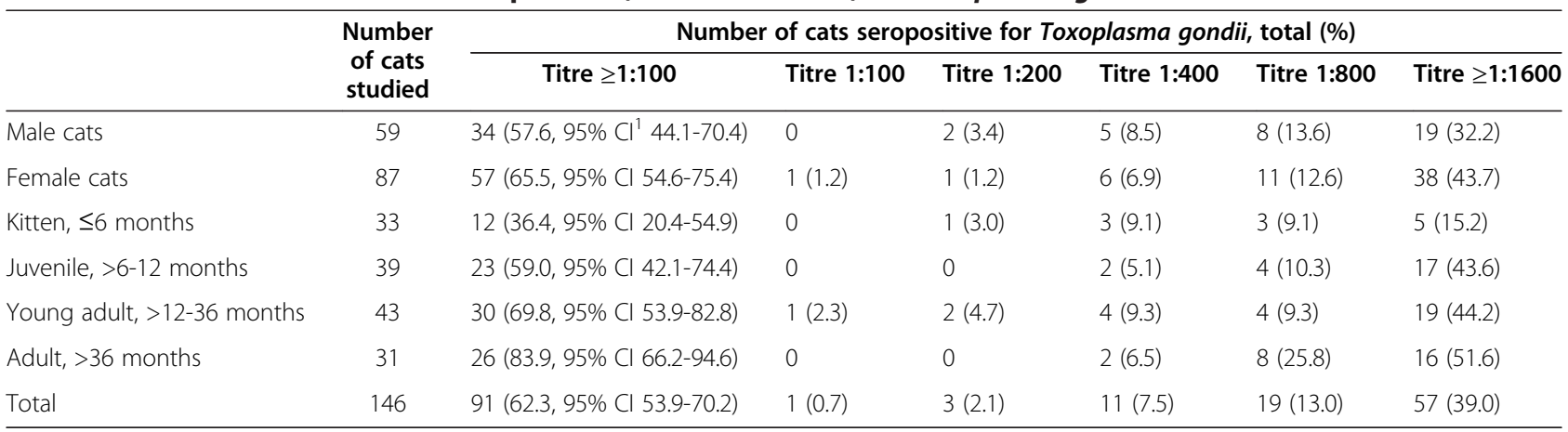

${ }^{1} 95 \% \mathrm{Cl}=95 \%$ confidence interval.

Antibodies (IFAT titre $\geq 1: 100$ ) to $N$. caninum were found in 15 of 146 cats $(10.3 \%, 95 \%$ CI 5.9 - 16.4), with titres of $1: 100$ in nine cats $(6.2 \%), 1: 200$ in five cats (3.4\%), and $1: 400$ in one cat $(0.7 \%)$ (Table 3$)$. Borderline IFAT titres of 1:50 were obtained for a further 40 cats, with 28 and seven of them showing T. gondii IFAT titres of $\geq 1: 800$ or $1: 50$ to $1: 400$, respectively, while the serum of the remaining five cats did not show reactivity to $T$. gondii.

In addition, one $(0.7 \%, 95 \% \mathrm{CI}, 0.02-3.76)$ and three (2.1\%, 95\% CI 0.4-5.9) serum samples tested positive for antibodies to L. infantum (IFAT titre 1:256) or A. phagocytophilum (IFAT titres 1:100, 1:200 or 1:800), respectively. Borderline 1:32 anti-L. infantum or 1:50 anti-AnaplasmaIFAT titres were observed in ten and eight cats, respectively. All ELISA tests were negative for circulating D. immitis antigen.

\section{Direct pathogen detection}

The blood of 1 out of 146 cats was positive for DNA of B. henselae $(0.7 \%, 95 \%$ CI, 0.02-3.76). DNA of three haemotropic mycoplasmas was detected in the blood of 45 cats (30.8\%): Candidatus M. haemominutum in 32 cats (21.9\%, 95\% CI 15.5-29.5), M. haemofelis in 15 cats (10.3\%, 95\% CI 5.9-16.4), and Candidatus M. turicensis in eight cats $(5.5 \%, 95 \%$ CI 2.4-10.5). Ten cats harboured co-infections of two mycoplasmas each (Table 4).

Microscopy of the blood smears did not reveal evidence for the presence of any pathogen, and all Knott's tests were negative. No blood sample was PCR-positive for DNA of A. phagocytophilum or L. infantum.

The overall prevalence of haemotropic mycoplasmas was significantly higher in male compared to female cats ( $40.6 \%$ vs. $24.1 \%, p=0.0444$ ); however, there was no significant association of either sex to the seroprevalences of T. gondii (57.6\% and $65.5 \%$, respectively) and $N$. caninum (10.2\% and $10.3 \%$, respectively). Age was associated positively with the frequency of anti-T. gondii antibodies $(\mathrm{p}=0.0008)$ and the prevalence of haemotropic mycoplasmas $(p=0.0454)$, but there was no association with age for the seropositivity for $N$. caninum. There was no significant difference in the prevalence of haemotropic mycoplasmas for the two seasons of collection (summer: $25 / 75$, 33.3\% vs. autumn: $20 / 71,28.2 \%$, respectively) or the status of infestation with fleas (haemotropic mycoplasmapositive/flea-positive: $17 / 71,23.9 \%$ vs. haemotropic mycoplasma-positive/flea-negative: $28 / 75,37.3 \%$, respectively).

\section{Co-infections and exposure to multiple pathogens}

A total of 45 cats (30.8\%) showed evidence of exposure to and/or infection with two to four pathogens in combination (Table 5). The most common combinations were seropositivity of $T$. gondii plus mycoplasmas and seropositivity of both $T$. gondii and N. caninum. Overall haemotropic mycoplasma infection was not associated with the $T$. gondii status of the cats (haemotropic mycoplasmapositive/T. gondii-positive: 32/91, 35.2\% vs. haemotropic mycoplasma-positive/T. gondii-negative: $13 / 55,23.6 \%$, respectively). However, sero-assessment for $N$. caninum and T. gondii revealed that sera yielding anti-N. caninum antibodies were found significantly $(\mathrm{p}=0.0493)$ more frequently among the $T$. gondii-positive cats compared to the cats tested $T$. gondii-negative (N. caninum-positive/ T. gondii-positive: $13 / 91,14.3 \%$ vs. $N$. caninum-positive/ $T$. gondii-negative: $2 / 55,3.6 \%$, respectively).

\section{Discussion}

This is the first study documenting seroprevalence of T. gondii, N. caninum, L. infantum and Anaplasma spp., and the molecular detection and prevalence of $B$. henselae and three haemotropic mycoplasmas in cats in Tirana, Albania.

\section{Toxoplasma gondii}

Toxoplasma gondii is one of the most prevalent cosmopolitan parasites, which can infect a wide spectrum of warm-blooded vertebrates. Based on its zoonotic nature, toxoplasmosis is one major public health issue worldwide and thus monitored closely in human medicine, but it is also considered as an important cause of 
Table 3 Details of cats that tested seropositive (IFAT titre $\geq 1: 100$ ) for Neospora caninum

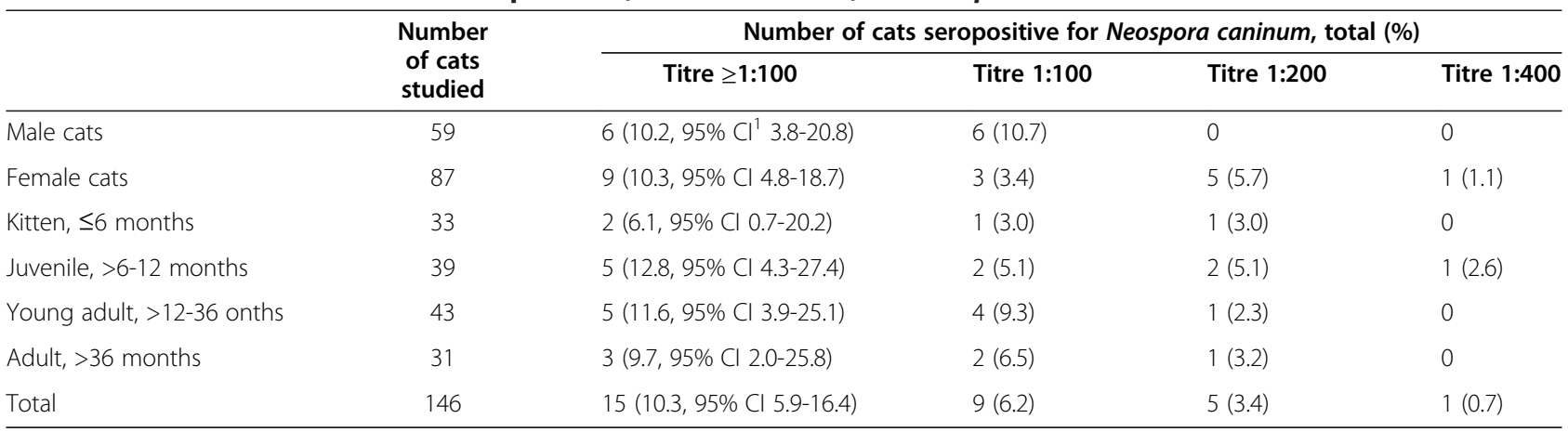

${ }^{1} 95 \% \mathrm{Cl}=95 \%$ confidence interval.

reproductive disease in small ruminants. Felids, including domestic cats, are the only definitive hosts of this parasite. As cats are shedding Toxoplasma oocysts only for a short period, sero-surveys are suitable measures to study the epidemiology of the pathogen, and they can be used as an indicator of the environmental contamination [17-19]. Toxoplasmosis is widespread in south-east Europe [20]. The average prevalence of IgG antibodies was reported to be approximately $50 \%$ in pregnant woman in Albania [21] and among Albanians who migrated to Italy [22] and this percentage of exposure represents the upper limit of the range of currently reported data from the Balkans [23-25]. The overall seroprevalence of $62.3 \%$ in the cats from Tirana is among the highest infection percentage observed in Europe where $T$. gondii antibodies were detected in up to $70 \%$ of the cats [26]. Recently seroprevalences of $47 \%$ to $81 \%$ were reported in cats in Romania $[27,28]$ or of almost $48 \%$ in Hungary [29]. Consistent with several other studies, the $T$. gondii seroprevalence in the cats from Tirana was positively associated with the age of the cats $[28,29]$. The association between seropositivity and gender, however, is unclear: in most surveys, including this study, the overall prevalence of infection in male and female cats did not differ significantly $[27,28]$; but there are some studies that found T. gondii exposure significantly more often among female cats $[29,30]$. The high prevalence of T. gondii antibodies in the cats from Tirana, Albania, is certainly related to their origin from suburban habitats with constant access to the outdoors, which has been identified as a risk factor of the infection [28]. The prevalence of antibodies to $T$. gondii in pregnant women in Albania was similar to the proportion observed in other parts of Europe. Beside consumption of undercooked meat, 'direct soil contact' has been thought to be associated with the seropositivity [21]. Therefore, given the high percentage of exposure to $T$. gondii in cats from Tirana, the seroprevalence of $T$. gondii in cats should be monitored further as it gives an indication of the contamination of the environment with oocysts and thus the potential implication for public health. Furthermore, the public should be informed about the risks of undercooked meat consumption.

\section{Neospora caninum}

Neospora caninum is primarily associated with dogs and cattle, and neosporosis continues to be an important cause of abortion in cattle. Felines belong to the wide spectrum of domestic and wild animals that are exposed

Table 4 Details of cats that tested positive for haemotropic mycoplasmas

\begin{tabular}{|c|c|c|c|c|c|c|c|}
\hline & \multirow{2}{*}{$\begin{array}{l}\text { Number } \\
\text { of cats } \\
\text { studied }\end{array}$} & \multicolumn{6}{|c|}{ Number of cats tested positive for mycoplasmas, total (\%) } \\
\hline & & Any mycoplasma & $M h^{1}$ & $\mathrm{CMh}^{2}$ & $\mathrm{CMt} \mathrm{t}^{3}$ & $M h+C M h$ & $\mathrm{CMh}+\mathrm{CMt}$ \\
\hline Male cats & 59 & $24\left(40.7,95 \% \mathrm{Cl}^{4} 28.1-54.3\right)$ & $5(8.5)$ & $19(32.2)$ & $7(11.9)$ & $3(5.1)$ & $4(6.8)$ \\
\hline Female cats & 87 & $21(24.1,95 \%$ Cl 15.6-34.5) & $10(11.5)$ & $13(14.9)$ & $1(1.2)$ & $3(3.5)$ & 0 \\
\hline Kitten, $\leq 6$ months & 33 & $4(12.1,95 \%$ Cl 3.4-28.2) & $1(3.0)$ & $4(12.1)$ & $1(3.0)$ & $1(3.0)$ & $1(3.0)$ \\
\hline Juvenile, $>6-12$ months & 39 & $12(30.8,95 \%$ Cl 17.0-47.6) & $2(5.1)$ & $7(18.0)$ & $3(7.7)$ & 0 & 0 \\
\hline Young adult, >12-36 months & 43 & 16 (37.2, 95\% Cl 23.0-53.3) & $7(16.3)$ & $11(25.6)$ & $3(7.0)$ & $3(7.0)$ & $2(4.7)$ \\
\hline Adult, $>36$ months & 31 & $13(41.9,95 \%$ Cl 24.6-60.9) & $5(16.1)$ & $10(32.3)$ & $1(3.2)$ & $2(6.5)$ & $1(3.2)$ \\
\hline Total & 146 & $45(30.8,95 \%$ Cl 23.5-39.0) & $15(10.3)$ & $32(21.9)$ & $8(5.5)$ & $6(4.1)$ & $4(2.7)$ \\
\hline
\end{tabular}

${ }^{1} \mathrm{Mh}=$ Mycoplasma haemofelis.

${ }^{2} \mathrm{CMh}=$ Candidatus Mycoplasma haemominutum.

${ }^{3} \mathrm{CMt}=$ Candidatus Mycoplasma turicensis.

${ }^{4} 95 \% \mathrm{Cl}=95 \%$ confidence interval. 
Table 5 Single and combined seropositivity and/or infection in 146 cats from Tirana, Albania

\begin{tabular}{|c|c|}
\hline & $\begin{array}{l}\text { Prevalence, } \\
\text { total }(\%)\end{array}$ \\
\hline Single seropositivity or infection in cats & $61(41.8)$ \\
\hline Toxoplasma gondii ${ }^{7}$ & $50(34.2)$ \\
\hline Neospora caninum ${ }^{\prime}$ & $1(0.7)$ \\
\hline Bartonella henselae & $1(0.7)$ \\
\hline Mycoplasma haemofelis & $3(2.1)$ \\
\hline Candidatus Mycoplasma haemominutum & $5(3.4)$ \\
\hline Candidatus Mycoplasma turicensis & $1(0.7)$ \\
\hline Combined seropositivity and/or infection in cats & $45(30.8)$ \\
\hline T. gondii + N. caninum & $5(3.4)$ \\
\hline T. gondii + Leishmania infantum ${ }^{2}$ & $1(0.7)$ \\
\hline T. gondii + Anaplasma phagocytophilum ${ }^{1}$ & $3(2.1)$ \\
\hline T. gondii + M. haemofelis & $5(3.4)$ \\
\hline T. gondii + Candidatus M. haemominutum & $12(8.2)$ \\
\hline T. gondii + Candidatus M. turicensis & $2(1.4)$ \\
\hline M. haemofelis + Candidatus M. haemominutum & $2(1.4)$ \\
\hline Candidatus M. haemominutum + Candidatus M. turicensis & $1(0.7)$ \\
\hline T. gondii + N. caninum + M. haemofelis & $1(0.7)$ \\
\hline T. gondii + N. caninum + Candidatus M. haemominutum & $5(3.4)$ \\
\hline T. gondii + N. caninum + Candidatus M. turicensis & $1(0.7)$ \\
\hline T. gondii + M. haemofelis + Candidatus M. haemominutum & $3(2.1)$ \\
\hline $\begin{array}{l}\text { T. gondii + Candidatus M. haemominutum + Candidatus } \\
\text { M. turicensis }\end{array}$ & $2(1.4)$ \\
\hline $\begin{array}{l}\text { N. caninum + M. haemofelis + Candidatus M. } \\
\text { haemominutum }\end{array}$ & $1(0.7)$ \\
\hline $\begin{array}{l}\text { T. gondii + N. caninum + Candidatus M. haemominutum + } \\
\text { Candidatus M. turicensis }\end{array}$ & $1(0.7)$ \\
\hline
\end{tabular}

${ }^{1}$ Seropositivity, IFAT titre $\geq 1: 100$.

${ }^{2}$ Seropositivity, IFAT titre $\geq 1: 64$.

to $N$. caninum, but neither Neospora have been isolated from them nor were clinical signs of disease reported [31]. For Albania, there is no information on the prevalence of $N$. caninum in cattle, but a recently conducted study estimated a seroprevalence of $18.3 \%$ in dogs (Hamel et al., unpublished). Sero-surveys in cats indicated 0 to almost $25 \%$ prevalence in domestic cats [29,32-36]. The seroprevalence observed in the Tirana cats was thus in the range of results of other surveys, and consistent with a study from Italy [32].

Seropositivity was not associated to the age or sex of the cats. However, other studies found a positive correlation of the anti- $N$. caninum antibody prevalence and the cats' age $[33,35,36]$. As indicated through the significant association of positive samples for $N$. caninum and $T$. gondii antibodies in this study (including the considerable number of cats with borderline anti- $N$. caninum titres) and similar observations in other studies $[34,35]$, serological cross-reactions between these two closely related apicomplexan protozoa cannot be ruled-out because $N$. caninum and $T$. gondii share common antigens [37].

\section{Anaplasma spp.}

None of the blood smears were positive for morulae, and no $A$. phagocytophilum-DNA was detected in any blood sample, but exposure to Anaplasma infection has been demonstrated through low titres in the serum of three cats (2.1\%) using the commercial A phagocytophilum-IFAT. Similar results were obtained previously when cat sera from Spain were tested [38,39]. In contrast, $40 \%$ of 30 dogs from Tirana tested positive with an A. phagocytophilum-IFAT [4], and in a recently completed study with 602 dogs under veterinary care from Albania, a seropositivity of $24 \%$ was established (Hamel et al., unpublished). The main vector of $A$. phagocytophilum in Europe, the tick Ixodes ricinus, is abundant in Albania and has been recorded on dogs in the city and district of Tirana in the past [40]. However, recently conducted surveys revealed $R$. sanguineus as the predominating species of ticks parasitizing dogs from Tirana while I. ricinus was recovered from single animals in low numbers only [6]. On cats from Tirana, however, no I. ricinus at all, but few $R$. sanguineus ticks were found previously [9] as well as in the present study. The occurrence of two anaplasmas, A. phagocytophilum and $A$. platys, has been confirmed in blood samples of dogs from Albania with the latter species dominating (Hamel et al, unpublished). A. platys is thought to be transmitted by $R$. sanguineus [41] and feline A. platys infections have been reported previously [42]. Crossreactivity of serum samples between $A$. phagocytophilum and $A$. platys antigens have been described in dogs [43-45]. Thus, seropositivity detected with the commercial A. phagocytophilum-IFAT in the cats in this study may be attributed to infection with either of the two or both anaplasmas.

\section{Leishmania infantum}

Albania belongs to the countries where zoonotic visceral leishmaniosis is endemic, and the disease is of great relevance in humans [46-48]. Competent vectors of L. infantum, the causative agent of human and canine leishmaniosis in Albania [49], are abundant in the country [50], and their occurrence was also documented for the district and city of Tirana [51]. Sero-surveys conducted in Albania indicated average anti-Leishmania antibody prevalences of $4-5.1 \%$ in dogs of different categories and geographic origin [3] (Hamel et al., unpublished). In contrast to the situation in dogs, feline leishmaniosis occurs sporadically and usually only in regions where canine leishmaniosis is endemic. The recently proven infectiousness of cats to sand-flies re-emphasized the question of the role 
of felines in the epidemiology of leishmaniosis which is still not clear [52,53]. With only 1 out of 146 feline sera from Tirana testing as Leishmania-positive, the percentage of exposure of cats to the parasite in the present study was at the lower end of the wide range of findings reported from other countries in the south of mainland Europe [54-58] and is much lower than the 5.1\% seroprevalence recorded in dogs from Tirana (Hamel et al., unpublished). For the Balkans, information on feline leishmaniosis is available apparently through two recently conducted serosurveys in Greece only. For both studies, serum samples were collected from stray cats in the Thessaloniki area, but the seroprevalences determined differed substantially with $21.6 \%$ [59] or $3.9 \%$ [60], respectively.

\section{Dirofilaria immitis}

Canine D. immitis is endemic in Albania [3-5,7], and several of its incriminated vectors are common representatives of the culicid fauna in the country [61]. However, microfilariae were not detected in any blood smears or by using the Knott's test neither was heartworm antigen detected in any serum sample of the cats from Tirana. Although canine heartworm infection was reported with increasing frequency from most of the countries of the Balkans in the recent past [7,62], the authors are not aware of any survey on feline dirofilariosis in the region. Similar to leishmaniosis, feline dirofilariosis is much less frequently diagnosed compared to canine dirofilariosis in a given region and, based on data collected in endemic areas, the prevalence of heartworm infection in cats can be expected to be $5 \%$ to $10 \%$ of that seen in dogs [63].

\section{Bartonella henselae}

As the main reservoir for $B$. henselae, the cat is a host which is often associated with Bartonella infections and with their transmission to man, while fleas have been proven to serve as vectors for transmission of the agents among cats $[64,65]$. Human disease associated to infection with Bartonella species as well as seropositivity to Bartonella spp. has been described from some countries in the Balkans $[66,67]$ but yet not from Albania. The prevalence of Bartonella infection in cats in the Balkan region is largely unknown. To the knowledge of the authors, there is only a small-scale survey from Serbia, which found that $57 \%$ of 40 cats had anti-B. henselae antibodies [68]. Bartonella henselae and B. clarridgeiae were demonstrated in $C$. felis fleas collected from seven cats from Tirana [10] including five cats studied in this survey. The single flea collected from the four months old, female kitten whose blood tested positive for $B$. henselae in the present study, however, did not harbour Bartonella-DNA [10]. In contrast, the positive fleas reported by Silaghi et al. (2012) were collected from cats negative for Bartonella spp. [10]. Thus, further studies are needed to understand the involvement of cats in the epidemiology of Bartonella infections in the Balkans.

\section{Haemotropic mycoplasmas}

Four haemotropic mycoplasmas have been recognized in cats: M. haemofelis, Candidatus M. haemominutum, Candidatus M. turicenis and Candidatus M. haematoparvum-like. These mycoplasmas differ in their pathogenicity, with $M$. haemofelis being the most virulent one that may cause severe haemolytic anaemia. The others may cause changes in blood parameters, but rarely cause diseases without concurrent infections; for the latter one no data is available. Subclinical infections with cats acting as carriers with subclinical infection are common. Feline haemotropic mycoplasma infections are believed to have a worldwide distribution with variable prevalence in the different populations of cats $[69,70]$. For Albania, this is the first study to document the occurrence and prevalence of three haemotropic mycoplasmas in cats, and it is the only other study on feline haemotropic mycoplasma infection from the Balkans beside one report from Greece [71]. The overall proportion of haemotropic mycoplasma infection of almost $31 \%$ as well as the prevalence of the individual mycoplasmas, including the percentage of co-infections, were within the range of results obtained in other studies in Europe [71-75]. The highest overall prevalence of haemotropic mycoplasmas in Europe (43.4\%) was found in a recently reported study from Portugal, where all four feline haemotropic mycoplasmas were identified, with all four mycoplasmas co-infecting one cat [76]. In line with some other studies, male sex $[69,71,72]$ and older age $[16,71,77,78]$ were found significantly associated with the detection of haemotropic mycoplasma DNA in the cats from Tirana. Contradictory to Gentilini et al. (2009), who suggested an association of summer season and higher prevalence of feline haemotropic mycoplasma infection because of a higher ectoparasite load which facilitates vectorial transmission of infections, own data and results of studies from Germany and Portugal [72,76,79] do not indicate a positive correlation of the presence of bloodfeeding arthropods and feline haemoplasmosis. Furthermore, analysis for mycoplasma DNA of all fleas collected from the cats in this study revealed only DNA of Candidatus M. haemominutum in two single $C$. felis fleas from two cats (unpublished data). One of those cats was a kitten that tested positive for $B$. henselae but was negative for haemotropic mycoplasma infection and had one flea only; the other cat was infected with Candidatus M. haemominutum and had three fleas. Both, the lack of correlation of the presence of blood-feeding arthropods and detection of DNA of haemotropic mycoplasmas and the marked discrepancy between the detection percentages of haemotropic mycoplasmas in the cats and in their fleas support hypotheses of the existence of routes of 
transmission of these bacterial organisms other than fleas acting as vectors. Aggressive interaction, such as cat bites, has been suggested as the possible route of transmission and this is supported by the higher prevalence in older and male cats seen in the present study [70].

\section{Conclusion}

In conclusion, with the broad screening panel including direct and indirect methods applied in the present study, a wide spectrum of parasitic or vector-borne agents and/or exposure to them could be detected in Albanian cats from Tirana.

\section{Competing interests}

The authors declare that they have no competing interests.

\section{Authors' contributions}

MK, DR, IK and ES collected the samples. CS performed the laboratory examinations. CS, MK and SR analysed the data. CS and SR drafted the manuscript, which was critically revised by MK, DH and KP. All authors read and approved the final version of the manuscript.

\section{Acknowledgements}

We thank Dr. Sándor Hornok, Faculty of Veterinary Medicine, Szent Istvan University, Hungary for providing the N. caninum and T. gondii-positive feline serum samples. Further we acknowledge the excellent technical assistance of Andrea Mihalkov and Claudia Thiel.

\section{Disclaimer}

This document is provided for scientific purposes only. Any reference to a brand or trademark herein is for informational purposes only and is not intended for a commercial purpose or to dilute the rights of the respective owner(s) of the brand(s) or trademark(s).

\section{Author details}

${ }^{1}$ Chair of Comparative Tropical Medicine and Parasitology, Faculty of Veterinary Medicine, Ludwig-Maximilians-Universität München, Leopoldstraße 5, 80802 Munich, Germany. ${ }^{2}$ Merial GmbH, Kathrinenhof Research Center, Rohrdorf-Lauterbach, Germany. ${ }^{3}$ Universiteti Bujqësor, Fakulteti i Mjeksise Veterinare, Kodër Kamëz, Tirana, Albania.

Received: 14 October 2013 Accepted: 5 February 2014

Published: 11 February 2014

\section{References}

1. Seimensis A, Morelli D, Mantovani A: Zoonoses in the Mediterranean region. Ann Ist Super San 2006, 42:437-445.

2. Otranto D, Dantas-Torres F: Canine and feline vector-borne diseases in Italy: current situation and perspectives. Parasit Vectors 2010, 3:2.

3. Lazri T, Duscher G, Edelhofer R, Bytyci B, Gjino P, Joachim A: Infektionen mit arthropodenübertragenen Parasiten bei Hunden im Kosovo und in Albanien unter besonderer Berücksichtigung der Leishmanieninfektionen. Wiener Klin Wochenschr 2008, 120(Suppl 4):54-58.

4. Hamel D, Silaghi C, Knaus M, Visser M, Kusi I, Rapti D, Rehbein S, Pfister K: Detection of Babesia canis subspecies and other arthropod-borne diseases in dogs from Tirana, Albania. Wiener Klin Wochenschr 2009, 121(Suppl 3):42-45.

5. Xhaxhiu D, Kusi I, Rapti D, Kondi E, Postoli R, Rinaldi L, Dimitrova ZM, Visser M, Knaus M, Rehbein S: Principal intestinal parasites of dogs in Tirana, Albania. Parasitol Res 2011, 108:341-353.

6. Xhaxhiu D, Kusi I, Rapti D, Visser M, Knaus M, Lindner T, Rehbein S: Ectoparasites of dogs and cats in Albania. Parasitol Res 2009, 105:1577-1587.

7. Rapti D, Rehbein S: Seroprevalence of canine heartworm (Dirofilaria immitis) infection in Albania. Parasitol Res 2010, 107:481-485.

8. Knaus M, Kusi I, Rapti D, Xhaxhiu D, Winter R, Visser M, Rehbein S: Endoparasites of cats from the Tirana area and the first report on
Aelurostrongylus abstrusus (railliet, 1898) in Albania. Wiener Klin Wochenschr 2011, 123(Suppl 1):31-35.

9. Knaus M, Rapti D, Kusi I, Shukullari E, Postoli R, Xhaxhiu D, Winter R, Visser M, Rehbein S: Survey of Endo- and Ectoparasites of Cats from Tirana, Albania. Buenos Aires, Argentina: 23rd International Conference of the World Association for the Advancement in Veterinary Parasitology (WAAVP); 2011:232. Abstracts.

10. Silaghi C, Knaus M, Rapti D, Shukullari E, Pfister K, Rehbein S: Rickettsia felis and Bartonella spp. in fleas from cats in Albania. Vector-Borne Zoonotic Dis 2012, 12:76-77.

11. Mancianti F, Falcone ML, Giannelli C, Poli A: Comparison between an enzyme-linked immunosorbent assay using a detergent-soluble Leishmania infantum antigen and indirect immunofluorescence for the diagnosis of canine leishmaniosis. Vet Parasitol 1995, 59:13-21.

12. Jensen WA, Fall MZ, Rooney J, Kordick DL, Breitschwerdt EB: Rapid identification and differentiation of Bartonella species using a single-step PCR assay. J Clin Microbiol 2000, 38:1717-1722.

13. Watanabe M, Hisasue M, Hashizaki K, Furuichi M, Ogata M, Hisamatsu S, Ogi E, Hasegawa M, Tsuchiya R, Yamada T: Molecular detection and characterization of Haemobartonella felis in domestic cats in Japan employing sequence-specific polymerase chain reaction (SS-PCR). $J$ Vet Med Sci 2003, 65:1111-1114.

14. Mary C, Faraut F, Lascombe L, Dumon H: Quantification of Leishmania infantum DNA by a real-time PCR assay with high sensitivity. J Clin Microbiol 2004, 42:5249-5255.

15. Courtney JW, Kostelnik LM, Zeidner NS, Massung RF: Multiplex real-time PCR for detection of Anaplasma phagocytophilum and Borrelia burgdorferi. J Clin Microbiol 2004, 42:3164-3168.

16. Willi B, Boretti FS, Baumgartner C, Tasker S, Wenger B, Cattori V, Meli ML, Reusch CE, Lutz H, Hofmann-Lehmann R: Prevalence, risk factor analysis, and follow-up of infections caused by three feline hemoplasma species in cats in Switzerland. J Clin Microbiol 2006, 44:961-969.

17. Tenter AM, Heckeroth AR, Weiss LM: Toxoplasma gondii: from animals to humans. Int J Parasitol 2000, 30:1217-1258.

18. Dabritz HA, Conrad PA: Cats and Toxoplasma: implications for public health. Zoon Publ Health 2010, 57:34-52.

19. Elmore SA, Jones JL, Conrad PA, Patton S, Lindsay DS, Dubey JP: Toxoplasma gondii: epidemiology, feline clinical aspects, and prevention. Trends Parasitol 2010, 26:190-196.

20. Bobić B, Klun I, Nikolić A, Djurković-Djaković O: Toxoplasma gondii-infection in south-east Europe: epidemiology and epizootiology. In Toxoplasmosis Recent Advances. Edited by Djurković-Djaković O. Rijeka, Croatia: InTech; 2012:37-54.

21. Maggi P, Volpe A, Carito V, Schinaia N, Bino S, Basho M, Dentico P. Surveillance of toxoplasmosis in pregnant women in Albania. New Microbiol 2009, 32:89-92.

22. Ventura MT, Munno G, Giannoccaro F, Accettura F, Chironna M, Lama R, Hoxha M, Panetta V, Ferrigno L, Rosmini F, Matricardi PM, Barbuti S, Priftanji A, Bonini S, Tursi A: Allergy, asthma and markers of infections among Albanian migrants to Southern Italy. Allergy 2004, 59:632-636.

23. Bobić B, Nikolić A, Klun I, Djurković-Djaković O: Kinetics of Toxoplasma infection in the Balkans. Wiener Klin Wochenschr 2011, 123(Suppl 1):2-6.

24. Dentico P, Volpe A, Putoto G, Ramadani N, Bertinato L, Berisha M, Schinaia N, Quaglio G, Maggi P: Toxoplasmosis in Kosovo pregnant women. New Microbiol 2011, 34:203-207.

25. Mancianti F, Nardoni S, Ariti G, Parlanti D, Giuliani G, Papini RA: Cross-sectional survey of Toxoplasma gondii infection in colony cats from urban Florence (Italy). J Feline Med Surg 2010, 12:351-354.

26. Michalski MM, Platt-Samoraj A, Mikulska-Skupień E: Toxoplasma gondii antibodies in domestic cats in Olsztyn urban area, Poland. Wiad Parazytol 2010, 56:277-279.

27. Darabus G, Hotea I, Oprescu I, Morariu S, Brudiu I, Olariu RT: Toxoplasmosis seroprevalence in cats and sheep from western Romania. Rev Med Vet 2011, 162:316-320.

28. Györke A, Opsteegh M, Mircean V, lovu A, Cozma V: Toxoplasma gondii in Romanian household cats: evaluation of serological tests, epidemiology and risk factors. Prev Vet Med 2011, 102:321-328.

29. Hornok S, Edelhofer R, Joachim A, Farkas R, Berta K, Répási A, Lakatos B: Seroprevalence of Toxoplasma gondii and Neospora caninum infection of cats in hungary. Acta Vet Hung 2008, 56:81-88. 
30. Jittapalapong S, Nimsupan B, Pinyopanuwat N, Chimnoi W, Kabeya H, Maruyama S: Seroprevalence of Toxoplasma gondii antibodies in stray cats and dogs in the Bangkok metropolitan area, Thailand. Vet Parasitol 2007, 145:138-141.

31. Dubey JP, Schares G: Neosporosis in animals-the last five years. Vet Parasitol 2011, 180:90-108.

32. Ferroglio E, Guiso P, Pasino M, Accossato A, Trisciuoglio A: Antibodies to Neospora caninum in stray cats from north Italy. Vet Parasitol 2005, 131:31-34.

33. Bresciani KDS, Gennai SM, Serrano ACM, Rodrigues AAR, Ueno T, Franco LG, Perri SHV, Amarante AFT: Antibodies to Neospora caninum and Toxoplasma gondii in domestic cats from Brazil. Parasitol Res 2007, 100:281-285.

34. Millán J, Cabezón O, Pabón M, Dubey JP, Almería S: Seroprevalence of Toxoplasma gondii and Neospora caninum in feral cats (Felis silvestris catus) in Majorca, Balearic Islands, Spain. Vet Parasitol 2009, 165:323-326.

35. Dourado Coelho WM, Amarante AF S d, de Carvalho Apolinário J, Dourado Coelho NM, de Lima VM F, Perri SHV, Bresciani KDS: Seroepidemiology of Toxoplasma gondii, Neospora caninum, and Leishmania spp. Infections and risk factors for cats from Brazil. Parasitol Res 2011, 109:1009-1013.

36. Hamidinejat H, Mosalanejad B, Avizeh R, Jalali MHR, Ghorbanpour M, Namavari M: Neospora caninum and Toxoplasma gondii antibody prevalence in Ahvaz feral cats, Iran. Jundishapur J Microbio/ 2011, $4: 217-222$.

37. Bjerkas I, Jenkins MC, Dubey JP: Identification and characterization of Neospora caninum tachyzoite antigens useful for diagnosis of neosporosis. Clin Diag Lab Immunol 1994, 1:214-221.

38. Aguirre E, Tesoro MA, Amusategui I, Rodríguez-Franco F, Sainz A: Assessment of feline ehrlichiosis in central Spain using serology and a polymerase chain reaction technique. Ann N Y Acad Sci 2004, 1026:103-105.

39. Solano-Gallego L, Hegarty B, Espada Y, Llull J, Breitschwerdt E: Serological and molecular evidence of exposure to arthropod-borne organisms in cats from northeastern Spain. Vet Microbiol 2006, 118:274-277.

40. Gina A: Të dhëna faunistike mbi rriqnat e familjes ixodidae në rrethin e tiranës. Bul Shkencave Nat 1973, 2:73-86.

41. Sanogo YO, Davoust B, Inokuma H, Camicas JL, Parola P, Brouqui P: First evidence of Anaplasma platys in Rhipicephalus sanguineus (Acari: ixodida) collected from dogs in Africa. Onderstepoort J Vet Res 2003, 70:205-212.

42. Lima MLF, Soares PT, Ramos CAN, Araújo FR, Ramos RAN, Souza IIF, Faustino MAG, Alves LCA: Molecular detection of Anaplasma platys in a naturally-infected cat in Brazil. Braz J Microbiol 2010, 41:381-385.

43. Beaufils JP, Inokuma H, Martin-Granel J, Jumelle P, Barbault-Jumelle M, Brouqui P: Anaplasma platys (Ehrlichia platys) infection in a dog in France: description of the case, and characterization of the agent. Rev Med Vet 2002, 153:85-90.

44. Inokuma H, Fujii K, Matsumoto K, Okuda M, Nalagome K, Kosugi R, Hirakawa M, Onishi T: Demonstration of Anaplasma (Ehrlichia) platys inclusions in peripheral blood platelets of a dog in Japan. Vet Parasitol 2002, 110:145-152.

45. Santos AS, Alexandre N, Sousa R, Núncio MS, Bacellar F, Dumler JS: Serological and molecular survey of Anaplasma species infection in dogs with suspected tickborne disease in Portugal. Vet Rec 2009, 164:168-171.

46. Sotira B: Zoonotic diseases of major concern in Albania. WHO Mediterranean zoonoses control centre. Info Circul 2000, 49:6-8

47. Lito G, Davachi F, Sulcebe G, Bregu H, Basha M: Pediatric visceral leishmaniasis in Albania. Int J Inf Dis 2002, 6:66-68.

48. Petrela R, Kuneshka L, Foto E, Zavalani F, Gradoni L: Pediatric visceral leishmaniasis in Albania: a retrospective analysis of 1,210 consecutive hospitalized patients (1995-2009). PloS Negl Trop Dis 2010, 4:e814

49. Cani E, Petrela R, Myrseli T, Fuga L, Minarolli P, Hyskaj M: Identification of two visceral Leishmania strains isolated in Tirana, Albania. Clin Microbiol Inf 2001, 7(Suppl 1):346.

50. Velo E, Paparisto A, Bongiorno G, Di Muccio T, Khoury C, Bino S, Gramoccia M, Gradoni L, Maroli M: Entomological and parasitological study on phlebotomine sandflies in central and northern Albania. Parasite 2005, 12:45-49.

51. Adhami J, Miho $V$, Murati N: Fauna e flebotomëve të qytetit të Tiranës, disa fshatrave përreth tij dhe rëndësia epidemiologjike e tyre. Rev Mjekësore 1988, 4:9-12.
52. Gramiccia M: Recent advances in leishmaniosis in pet animals: epidemiology, diagostics and anti-vectorial prophylaxis. Vet Parasitol 2011, 181:23-30.

53. Maia C, Campino L: Can domestic cats be considered reservoir hosts of zoonotic leishmaniasis? Trends Parasitol 2008, 27:341-344.

54. Solano-Gallego L, Rodríguez-Cortés A, Iniesta L, Quintana J, Pastor J, Espada Y, Portús M, Alberala J: Cross-sectional serosurvey of feline leishmaniasis in ecoregions around the Northwestern Mediterranean. Am J Trop Med Hyg 2007, 76:676-680.

55. Ayllón T, Tesuoro MA, Amutsategui I, Villaescusa A, Rodríguez-Franco F, Sainz A: Serologic and molecular evaluation of Leishmania infantum in cats from central Spain. Ann N Y Acad Sci 2008, 1149:361-364.

56. Maia C, Gomes J, Cristóvão J, Nunes M, Martins A, Rebêlo E, Campino L: Feline Leishmania infection in a canine leishmaniasis endemic region, Portugal. Vet Parasitol 2010, 174:336-340.

57. Cardoso L, Lopes AP, Sherry K, Schallig H, Solano-Gallego L: Low seroprevalence of Leishmania infantum infection in cats from northern Portugal based on DAT and ELISA. Vet Parasitol 2010, 174:37-42.

58. Pennisi MG, Lupo T, Masucci M, Migliazzo A, Lombardo G: Serological and molecular prevalence of Leishmania infantum infection in cats from southern Italy. J Feline Med Surg 2012, 14:656-657.

59. Huebner J, Müller E, Langbein-Detsch I, Naucke T: Serological survey of Leishmania infections in cats from north Greece. J Vet Int Med 2008, 22:782-783

60. Diakou A, Papadopoulos E, Lazarides K: Specific anti-Leishmania spp. antibodies in stray cats in Greece. J Feline Med Surg 2009, 11:728-730.

61. Adhami J, Reiter P: Introduction and establishment of Aedes (Stegomyia) albopictus skuse (Diptera: Culicidae) in Albania. J Am Mosq Contr Ass 1998, 14:340-343.

62. Tasić A, Tasić-Otašević S, Gabrielli S, Miladinović-Tasić N, Ignjatović A, Đorđević J, Dimitrijević S, Cancrini G: Canine Dirofilaria infections in two uninvestigated areas of Serbia: epidemiological and genetic aspects. Vector-borne Zoon Dis 2012, 12:1031-1035.

63. Litster AL, Atwell RB: Feline heartworm disease: a clinical review. $J$ Feline Med Surg 2008, 10:137-144.

64. Bitam I, Dittmar K, Parola P, Whiting MF, Raoult D: Fleas and flea-borne diseases. Int J Infect Dis 2010, 14:e667-e676.

65. Guptill L: Bartonella infection in cats: what is the significance? In Pract 2012, 34:434-445.

66. Pape M, Manraveli K, Alexiou-Daniel S: Clinical aspects of Bartonella infection in northern Greece. Clin Microbiol Infect 2009, 15(Suppl 2):91-92.

67. Vilibic-Cavlek T, Karlovoc-Martinovic D, Ljubin-Sternak S, Tabain I, Persic Z, Mlinaric-Galinovic G: High prevalence of Bartonella henselae and Bartonella quintana antibodies in Croatian patients presenting with lymphadenopathy. Polish J Microbio/ 2012, 61:315-318.

68. Potkonjak A, Lako B, Babić D, Lako B, Suvajdžić L, Stefančević M, Toholj B, Vraneš M: First report on seroepidemiological and clinical investigation of cat infection with Bartonella henselae in the area of Novi Sad, Serbia. Acta Vet (Beograd) 2011, 61:183-192.

69. Sykes JE: Feline hemotropic mycoplasmas. Vet Clin North Am Small Anim Pract 2010, 40:1157-1170.

70. Tasker S: Haemotropic mycoplasmas - what's their real significance in cats? J Feline Med Surg 2010, 12:369-381.

71. Maher IE, Tasker S, Polizopoulou Z, Dasopoulou A, Egan K, Helps CR, Papasouliotis K: Polymerase chain reaction survey of feline haemotropic mycoplasma infections in Greece. J Feline Med Surg 2010, 12:601-605.

72. Laberke S, Just F, Pfister K, Hartmann K: Prevalence of feline haemotropic mycoplasma infection in cats in Southern Bavaria, Germany, and infection risk factor analysis. Berl Munch Tierarztl Wochenschr 2010, 123:42-48.

73. Roura X, Peters IR, Altet L, Tabar M-D, Barker EN, Planellas M, Helps CR, Francino O, Shaw SE, Tasker S: Prevalence of hemotropic mycoplasmas in healthy and unhealthy cats and dogs in Spain. J Vet Diag Invest 2010, 22:270-274.

74. Willi B, Novacco M, Wolf-Jäckel GA, Boretti FS, Wengi N, Lutz H, HofmannLehmann R: Haemotropic mycoplasmas of cats and dogs: transmission, diagnosis, prevalence and importance in Europe. Schweiz Archiv Tierheilk 2010, 152:237-244.

75. Morgenthal D, Hamel D, Arndt G, Silaghi C, Pfister K, Kempf VAJ, Kohn B: Prävalenz von hämotrophen Mycoplasma spp., Bartonella spp. und 
Anaplasma phagocytophilum bei Katzen im Raum Berlin/Brandenburg. Berl Munch Tierarztl Wochenschr 2012, 125:418-427.

76. Martínez-Díaz V, Silvestre-Ferreira AC, Vilhena H, Pastor J, Francino O, Altet L: Prevalence and co-infection of haemotropic mycoplasmas in Portuguese cats by real-time polymerase chain reaction. J Feline Med Surg 2013, 15:879-885.

77. Tasker S, Binns SH, Day MJ, Gruffydd-Jones TJ, Harbour DA, Helps CR, Jensen WA, Oliver CS, Lappin MR: Use of a PCR assay to assess prevalence and risk factors for mycoplasma haemofelis and 'Candidatus M. haemominutum' in cats in the United Kingdom. Vet Rec 2003, 152:193-198.

78. Tasker S, Braddock JA, Baral R, Helps CR, Day MJ, Gruffydd-Jones TJ, Malik R: Diagnosis of feline haemotropic mycoplasma infection in Australian cats using a real-time PCR assay. J Feline Med Surg 2004, 6:345-354.

79. Gentilini F, Novacco M, Turba ME, Willi B, Bacci ML, Hofmann-Lehmann R: Use of combined conventional and real-time PCR to determine the epidemiology of feline haemotropic mycoplasma infections in northern Italy. J Feline Med Surg 2009, 11:277-285.

doi:10.1186/1756-3305-7-62

Cite this article as: Silaghi et al: Survey of Toxoplasma gondii and

Neospora caninum, haemotropic mycoplasmas and other arthropod-borne pathogens in cats from Albania. Parasites \& Vectors 2014 7:62.

\section{Submit your next manuscript to BioMed Central and take full advantage of:}

- Convenient online submission

- Thorough peer review

- No space constraints or color figure charges

- Immediate publication on acceptance

- Inclusion in PubMed, CAS, Scopus and Google Scholar

- Research which is freely available for redistribution 